\title{
The Development of Android Educational Game "MENALAR" for Ten Grade High School Students
}

\author{
Ryan Angga Pratama ${ }^{1}$, Rahayu Sri Waskitoningtyas ${ }^{2}$ \\ \{ryan.angga@uniba-bpn.ac.id ${ }^{1}$, rahayu.sri@uniba-bpn.ac.id ${ }^{2}$ \}
}

Universitas Balikpapan, Jl. Pupuk Raya Kelurahan Gunung Bahagia, Balikpapan, Indonesia ${ }^{1,2}$

\begin{abstract}
This study aims to produce distance learning media using Adobe Animation CC, namely educational game "MENALAR" which can be played on a smartphone. The product is developed by paying attention to the aspects of validity, practicality, and effectiveness in learning mathematics in X Grade of SMA Negeri 5 Balikpapan and SMA Negeri 6 Balikpapan. The implementation uses the Multimedia Development Life Cycle (MDLC) development design which consists of: concept, design, obtaining content material, assembly, testing, and distribution. These results were obtained from media testing consisting of Alpha and Beta test. The results of the study concluded that the "MENALAR" educational game was included in the very valid category with a percentage of $87,6 \%$, very practical with an average percentage of $83,6 \%$; and effective with a percentage of completeness reaching $61,8 \%$. So that overall the developed learning media can be an alternative in learning activities, especially regarding mathematical reasoning problems.
\end{abstract}

Keywords: Android, Adobe Animation CC, MENALAR.

\section{Introduction}

NCTM [1] argues that in learning mathematics students are required to have mathematical communication skills, mathematical reasoning, mathematical problem solving, mathematical connections, and mathematical representations. Thus, reasoning is one aspect of high-order mathematical thinking skills that students must have [2, 3]. In addition, the learning process in the 2013 Curriculum for the primary and secondary levels is carried out using a scientific approach which includes observation, asking, experimenting, processing information, presenting data, analyzing, reasoning, concluding and creating, and communicating [4]. Based on this, it is clear that mathematical reasoning ability is also a very important and essential aspect. Realizing the importance of mathematical reasoning in learning structures in the current curriculum, learning is needed that can improve students' mathematical reasoning. One way that can be used to improve students' mathematical reasoning and communication skills is to use learning media effectively and efficiently.

Based on the results of interviews with mathematics teachers at SMA Negeri 5 Balikpapan, teachers have used learning media such as Microsoft PowerPoint. However, the teacher did not invite students to think critically. This can be seen from examples of reasoning questions in textbooks that are rarely discussed so that students are not accustomed to being critical and constructing their own knowledge. Furthermore, with regard to the use of information and communication technology in the mathematics learning process, teachers more often ask 
students to learn by using Google Classroom, searching on Google, and watching YouTube. This really supports students to learn independently and construct their own knowledge, but also has the potential to be misused by students for just playing. For example, students tend to be engrossed in the learning process alone or play with their smartphones when the teacher is explaining.

As we known, the rapid technological advances have led to information technology-based learning processes using computers [5], or other devices such as smartphones. Today's cell phones are known as smartphones, enabling a variety of features, including multimedia. This feature has the potential to be used for educational purposes [6]. According to Pratama et al [7] and Bahauddin \& Setyaningrum [8], the use of android smartphones is currently more widely used as a means of entertainment than education. On the other hand, so many users of the Android in Indonesia [9], especially teenage or high school students, make it an opportunity for teachers to develop various learning media in digital era. So that, the development of smartphones is not only limited to communication tools, but nowadays it has been widely used as a learning media [10].

Learning on Android smartphone is one of the alternatives in learning that are fun and interesting [10]. One of the Android based learning media that is often used is games (in this reasearch: math games). Educational games are fun games or activities that contain educational content $[11,12]$. Another definition, educational games are a combination of education and entertainment designed to stimulate student thinking $[8,12,13]$. Research studies related to educational games also show positive results. It is known that educational games have a motivational effect in the classroom, and students get more learning opportunities than conventional learning [9]. In addition, educational games also have an effect on improving the academic performance of high school students and are effective on student learning outcomes $[14,15]$. Thus, it is clear that the use of games in the world of education is a form of renewal, which will provide various positive impacts in the learning process.

Based on the problems that have been described, also seeing the potential use of information and communication technology in learning in today's digital era and the importance of students' reasoning abilities, it is necessary to develop learning media products that can be used to support student learning and reasoning activities. The product is an educational game based on Adobe Animation CC which is named "MENALAR". According to Wibawanto [16], Adobe Animation CC is computer software designed by the Adobe System that can be used to create various types of projects including animation, interactive media, games, smartphone applications, and so on. The development of this learning media is very important; especially applying it in learning in the current conditions of the Covid-19 pandemic. By using educational games, students will be able to learn independently, be responsible, and are expected to improve their outcomes or mathematical reasoning.

\section{Method}

\subsection{Research Design}

This research is a research and development that is used to produce products and test the effectiveness of these products [17]. The development model uses Luther's design, namely Multimedia Development Life Cycle (MDLC) developed by Sutopo [18]. 


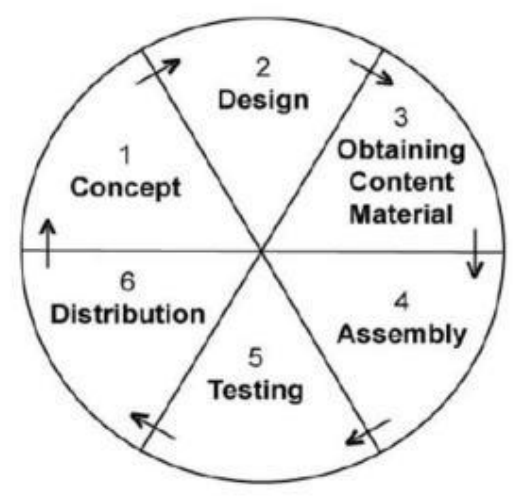

Fig. 1. MDLC Development Cycle

\subsection{Data Collection Techniques}

Data collection was carried out by means of documentation, tests, and questionnaires. The data collection instruments are as follows:

1. Documentation; Documentation in the form of photos or screenshots during the research.

2. Test; The test is in the form of 15 reasoning questions in X Grade material, namely: onevariable linear equations and inequalities, a three-variable system of linear equations, a two-variable linear inequality system, functions, and trigonometry.

3. Questionnaire; (a) Questionnaire for media experts; contains an assessment based on aspects of audio, software engineering, and visual appearance. (b) Questionnaire for material experts; contains an assessment based on the quality aspects of reasoning practice questions, and the effect on learning strategies. (c) Questionnaires for practitioners/teachers and students; contains assessments based on aspects of the quality of the content of reasoning questions, effects on learning strategies, and aspects of software engineering.

Furthermore, the Likert scale was used as a reference in preparing the questionnaire. The Likert scale provides five answer options with the following format: Strongly Disagree $=1$; Disagree $=2 ;$ Doubt $=3 ;$ Agree $=4$; and Strongly Agree $=5$ [17]. And then, the data analysis carried out was to analyze the validity, practicality, and effectiveness of the developed learning media.

\subsection{Analysis of Validity and Practicality}

The formula used is as follows [19]

$$
P=\frac{T S h}{T S e} \times 100 \%
$$

Note:

$P \quad$ : Validity or practicality's percentage

TSh: Expected score

TSe: Empirical score

The results of the analysis were then adjusted according to the interpretation of the scores as shown in the following table [20]. 
Table 1. Criteria for Validity or Practicality

\begin{tabular}{cc}
\hline Percentage (\%) & Criteria \\
\hline $80 \leq P \leq 100$ & Very Valid or Very Practical \\
$60 \leq P<80$ & Valid or Practical \\
$40 \leq P<60$ & Quite Valid or Practical Enough \\
$20 \leq P<40$ & Less Valid or Less Practical \\
$0 \leq P<20$ & Very Less Valid or Very Less Practical \\
\hline
\end{tabular}

\subsection{Effectiveness Analysis}

Analysis of the effectiveness of the educational game "MENALAR" was carried out on the results of the reasoning tests obtained by students. The data were then analyzed by counting the number of students who were able to achieve the Minimum Completeness Criteria (KKM in Indonesia) that had been determined by the school, namely the value of 73 . The data were interpreted into the effectiveness criteria with the following references [21].

Table 2. Effectiveness Criteria

\begin{tabular}{cc}
\hline Percentage (\%) & Criteria \\
\hline$p>80$ & Very effective \\
$60<p \leq 80$ & Effective \\
$40<p \leq 60$ & Effective enough \\
$20<p \leq 40$ & Less effective \\
$p \leq 20$ & Very Less Effective \\
\hline
\end{tabular}

Note:

$p:$ The percentage of students who score above the KKM

Based on the table, the educational game "MENALAR" can be said to be effective if the percentage of the number of students who reach a score above or equal to the KKM, which is more than $60 \%$ of the total number of students who have played the game.

\section{Results and Discussion}

The research and development results obtained using the Multimedia Development Life Cycle (MDLC) development method are described as follows.

\subsection{Concept}

The concept and purpose of making the application are to help students in learning mathematics, especially regarding reasoning problems. The concept of offering an educational game is in the form of practicing reasoning questions as many as 15 items with a maximum time limit for each question is 5 minutes. At the end, a discussion of each question is also given.

\subsection{Design}

At this stage, the material construct and design of a storyboard to describe the stages of each scene. 


\subsection{Obtaining Content Material}

Materials needed include: reasoning questions from several textbooks, pictures, animation, audio, and text. The equipment and equipment used are a laptop, USB flash disk, internet, and the Adobe Animation CC application.

\subsection{Assembly}

Following are some of the final displays of the "REALIZING" educational game products developed.

* Title Page and Display of Developer
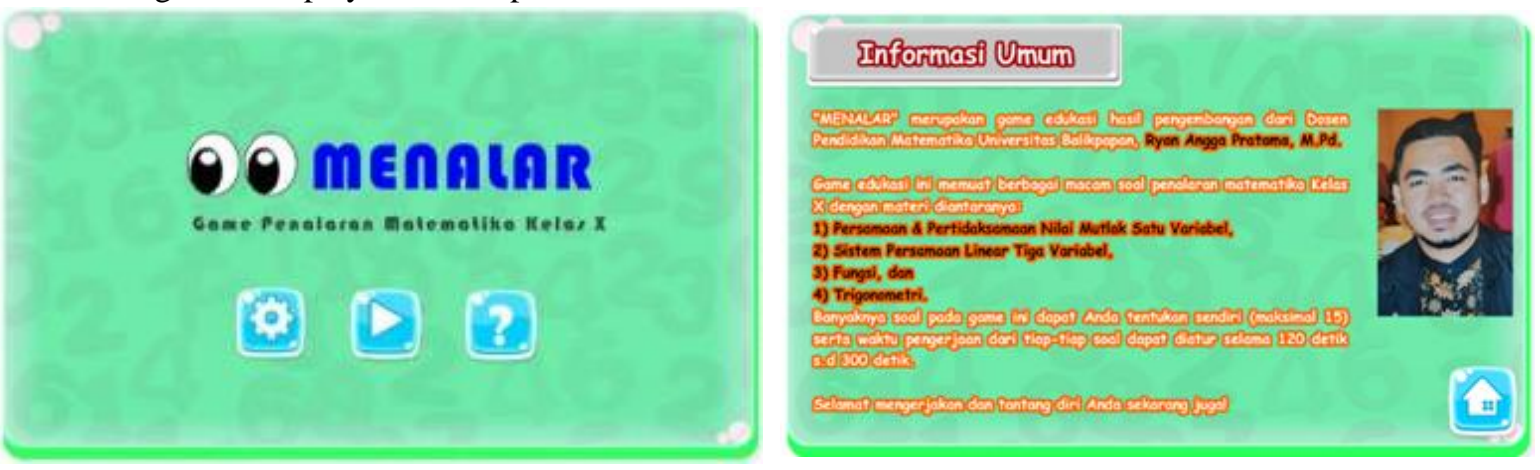

Fig. 2. Home Display

Fig. 3. Display of Developer (Researcher) Profile

* Correct and Wrong Answer Pop Up Display

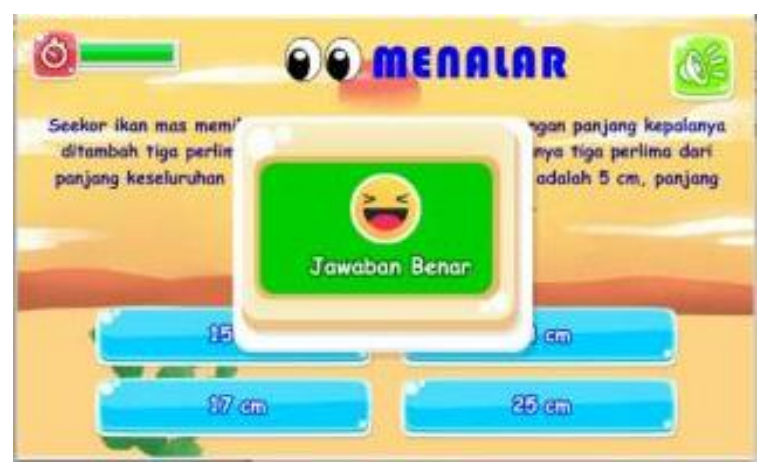

Fig. 4. Correct Answer Pop Up

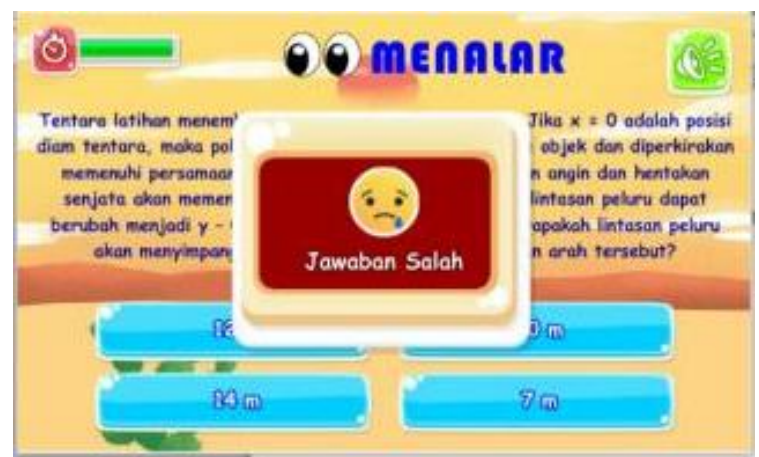

Fig. 5. Wrong Answer Pop Up 
Setting and Score Display

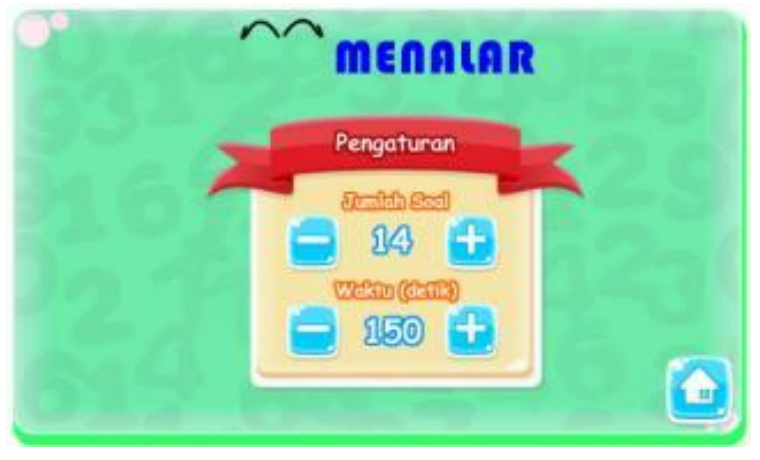

Fig. 6. Problem and Time Setting

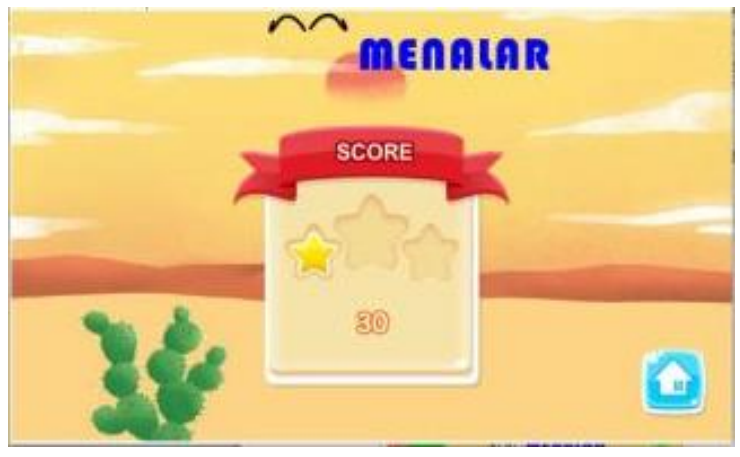

Fig. 7. Display Score at the End of Problem

\subsection{Testing}

There are two types of testing used, namely alpha and beta testing. The alpha test was conducted by two media experts, three material and learning evaluation experts, and three Mathematics learning practitioners. Meanwhile, the beta test is a test conducted by the user twice, namely small and large trials. For a small trial, the subjects were students of SMA Negeri 5 Balikpapan. While the large trial, the subjects are students of SMA Negeri 6 Balikpapan and students of SMA Negeri 5 Balikpapan.

The first process in testing is Alpha test. Alpha testing is carried out in one step to determine the feasibility of a learning media that is validated by 2 media experts, 3 material and learning evaluation experts, and also 3 learning practitioners. Due to the conditions of the Covid-19 Pandemic, all trials were carried out remotely.

\section{\# Alpha Test}

Media experts fill out a questionnaire via the link: http://bit.ly/AngketAhliMedia. Following are the results of the assessment.

Table 3. Results of the Media Expert's

\begin{tabular}{lcc}
\hline \multirow{2}{*}{ Indicator } & \multicolumn{2}{c}{ Alpha } \\
\cline { 2 - 3 } & Score of Expert 1 & Score of Expert 2 \\
\hline Sound effects & 5 & 4 \\
Backsound & 5 & 4 \\
Color composition & 5 & 5 \\
Font type & 5 & 5 \\
Font size & 5 & 5 \\
Text display & 5 & 4 \\
Image / object placement & 5 & 4 \\
Image proportions & 5 & 5 \\
Display design & 5 & 5 \\
Touch function & 5 & 5 \\
Game flow & 5 & 4 \\
Ease of operation & 5 & 4
\end{tabular}




\begin{tabular}{lcc} 
Ease of management & 5 & 5 \\
\hline Total & 65 & 55 \\
\hline Percentage & $100 \%$ & $84,6 \%$ \\
\hline Criteria & Very Valid & Very Valid \\
\hline
\end{tabular}

In general, based on Alpha testing with Media Experts, the comments given are positive. The following are the results of the comments: "MENALAR" Games are very interesting and can help teachers in IT-based individual learning. In addition, the game is easy to operate because it comes with instructions for use. The lack of the educational game "MENALAR" includes aspects of completeness of the content and function of the buttons. The following are the results of the comments: the game should be equipped with discussion of answer keys, especially questions that were answered incorrectly by the user, and motivational sentences for the user can be added. Therefore, it needs to be revised before being tested on students.

In addition, the educational game "MENALAR" is also validated by material and learning evaluation experts. They filled out a questionnaire via the link: http://bit.ly/AngketAhliMateri.

Table 4. Results of Material Expert's

\begin{tabular}{lccc}
\hline \multirow{2}{*}{ Indicator } & \multicolumn{3}{c}{ Alpha } \\
\cline { 2 - 4 } & Score of Expert 1 & Score of Expert 2 & Score of Expert 3 \\
\hline Textbook compatibility & 4 & 5 & 5 \\
KD conformity & 4 & 5 & 4 \\
Completeness of the questions & 4 & 4 & 4 \\
Systematically & 4 & 5 & 4 \\
The clarity of the discussion material & 4 & 4 & 4 \\
The clarity of the reasoning & 3 & 3 & 4 \\
questions & 4 & 5 & 4 \\
Problem according to the text book & 4 & 5 & 4 \\
Display clarity & 4 & 3 & 4 \\
The truth of the discussion about the & 4 & 4 & 4 \\
matter & 5 & 5 & 4 \\
Difficulty level suitability & 4 & 5 & 5 \\
Usefulness in learning motivation & 5 & 5 & 5 \\
Ease of independent study & 53 & 58 & 55 \\
Reasonable utility & $81,5 \%$ & $89,2 \%$ & Very Valid \\
\hline Total & Very Valid & Very Valid & \\
\hline Perscentage & & & 4 \\
\hline Criteria & 5 & 5 & 4 \\
\hline
\end{tabular}

In general, based on the results of the questionnaire analysis from the three material experts on the Alpha test, comments were obtained: the game presented is quite interesting but needs to be added to the discussion. Thus, the "MENALAR" needs to be revised before being tested on students. Finally, the educational game "MENALAR" was also validated by three learning practitioners. They filled out a questionnaire via the link: http://bit.ly/AngketPraktisi. The following results were obtained: 
Table 5. Results of Assessment of Learning Practitioners Alpha Test

\begin{tabular}{lccc}
\hline & \multicolumn{3}{c}{ Alpha } \\
\cline { 2 - 4 } Indicator & $\begin{array}{c}\text { Score of } \\
\text { Expert 1 }\end{array}$ & $\begin{array}{c}\text { Score of } \\
\text { Expert 2 }\end{array}$ & $\begin{array}{c}\text { Score of } \\
\text { Expert 3 }\end{array}$ \\
\hline Textbook compatibility & 4 & 5 & 5 \\
Compliance with KD & 4 & 5 & 4 \\
Completeness of reasoning questions from & 4 & 4 & 4 \\
the material & 4 & 5 & 4 \\
Systematically & 4 & 4 & 4 \\
The clarity of the material & 4 & 5 & 5 \\
The clarity of the reasoning questions & 4 & 5 & 4 \\
Problem according to the text book & 4 & 5 & 5 \\
The clarity of the question display & 4 & 5 & 4 \\
The truth of the discussion about the matter & 4 & 4 & 4 \\
Difficulty level suitability & 4 & 5 & 5 \\
Usefulness in learning motivation & 4 & 4 & 4 \\
Ease of independent study & 4 & 5 & 5 \\
Reasonable utility & 4 & 5 & 4 \\
Learning media innovation & 4 & 5 & 4 \\
Ease of operation & 4 & 4 & 5 \\
Educational game flow & 4 & 5 & 4 \\
Benefits in the world of education & 68 & 80 & $74 \%$ \\
\hline Total & Very Practical & Very Practical & Very Practical \\
\hline Percentage & & & \\
\hline Criteria & & & 5 \\
\hline
\end{tabular}

Based on the table above, overall the educational game "MENALAR" received a positive response. Following are the results of the comments: the game is good and in the future it can be used for all types of smartphones (Android and Iphone), and the steps for discussing the questions are necessary.

Based on advice of the experts, the researcher then revised the educational game "MENALAR" by adding a discussion in the final scene. Here's how it looks.

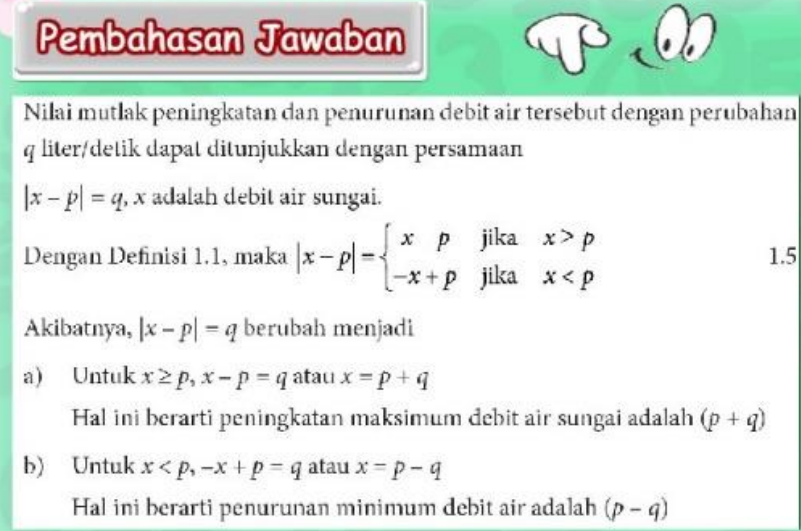


Fig. 8. Discussion View

So that, Based on the Alpha Test analysis, it can be said that the assessment of the android educational game "MENALAR" by 8 experts was $87,6 \%$ (included in the Very Valid category to be tested). After being revised, then Beta testing was carried out to see the practicality of the educational game "MENALAR" being developed. Beta Test is carried out in two steps, namely the small group test and the large group test.

\section{Beta Test}

The Small Group Test was held on April 30, 2020 on 15 subjects of class X-IPA-3 and 8 students of class X-IPA-4 of SMAN 5 Balikpapan. While the Large Group Beta Test was held on May 3, 2020 for 23 X-IPA-1 students, 13 X-IPA-2 students, 24 X-IPA-6 students, 14 X-IPS1 students at SMAN 5 Balikpapan, and 15 students of X-IPA-4 SMA Negeri 6 Balikpapan. Following are the results of the questionnaire responses.

Table 6. Beta Test Assessment Results

\begin{tabular}{lcc}
\hline \multirow{2}{*}{ Indicator } & Small & Large \\
\cline { 2 - 3 } & Score 23 students & Score 89 students \\
\hline Attractive appearance & 89 & 354 \\
Interesting sound effects & 82 & 304 \\
Easy touch function & 101 & 379 \\
Educational game flow & 87 & 338 \\
Ease of play & 91 & 340 \\
The clarity of the reasoning questions & 93 & 353 \\
Completeness of the reasoning questions & 97 & 365 \\
Completeness of the discussion questions & 96 & 361 \\
The suitability of the questions with the students' & 77 & 319 \\
abilities & 95 & 344 \\
Variative and fun learning & 91 & 345 \\
Ease and motivation for independent learning & 91 & 352 \\
Usefulness of knowledge & 94 & 356 \\
The benefits of reasoning & 1184 & 4510 \\
\hline Total & $79,1 \%$ & $77,9 \%$ \\
\hline Percentage & Practically & Practically \\
\hline Criteria & & \\
\hline
\end{tabular}

Based on the table above, it can be said that the android educational game "MENALAR" is included in the Practical category. Students also gave positive responses. The following include: (a) Interesting, fun and very helpful application, (b) Exercise is easy to understand, and (c) The application helps me to study independently. However, some of them provide comments or 
suggestions: (a) Please extend the time, (b) Don't be too serious in the song or the backsound, and (c) We recommend that you give the "Pause" button.

Overall, based on the results that have been explained, it can be said that the android educational game "MENALAR" which was carried out by 3 practitioners and 112 students was 83,6\% (Very Practical category).

\subsection{Distribution}

Applications are stored and distributed via smartphone devices as application package files (.apk). The distribution uses the following link: http://bit.ly/UnduhGameMENALAR. During the trial implementation, the mathematics teacher technically distributed the educational game "MENALAR" through the link provided by the researcher. The research implementation was also controlled remotely via the teacher's WhatsApp. Based on the teacher's report, it is known that their students are very enthusiastic about the games given. The teacher also asked students to collect the results of their calculations by being photographed. The following is a conversation between the researcher and the teacher and some of the calculation results of the students at SMAN 5 Balikpapan.

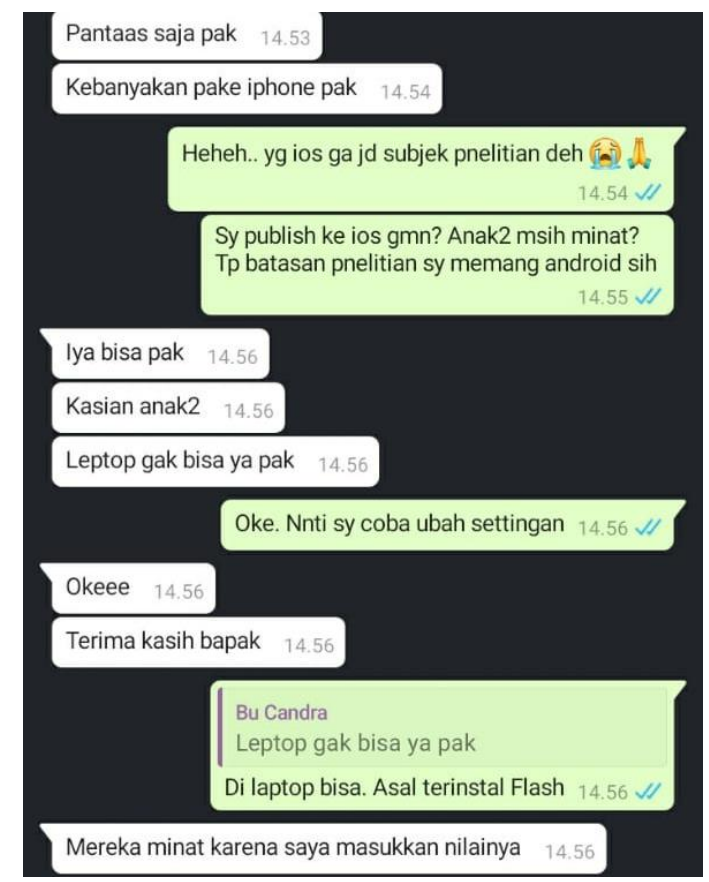

Fig. 9. Conversations between Researchers and Practitioners/Teachers 


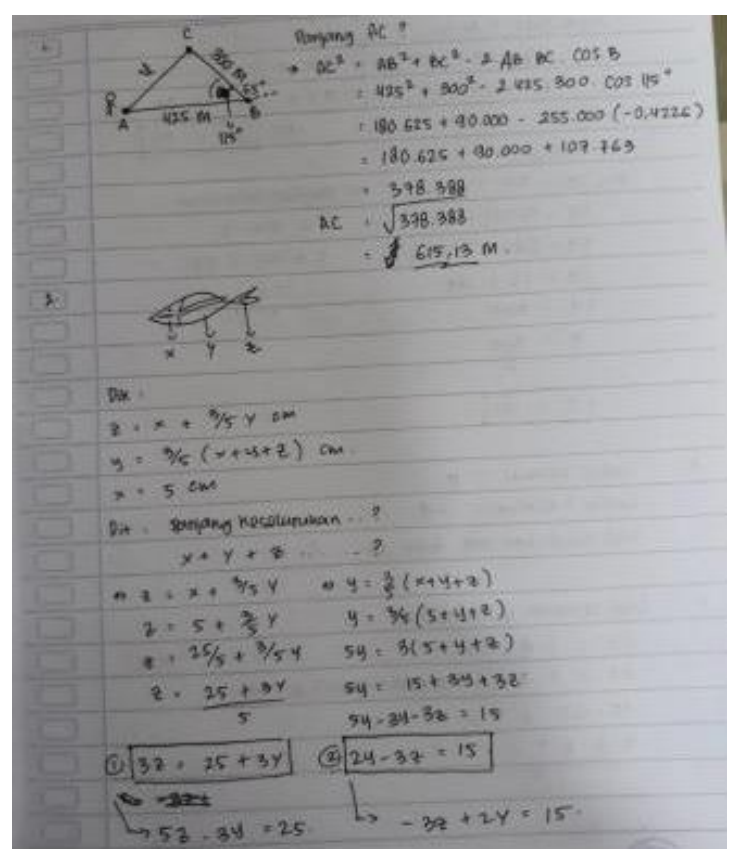

Fig. 10. Results of X-IPA-1 Student Work IPA-4 Student Work

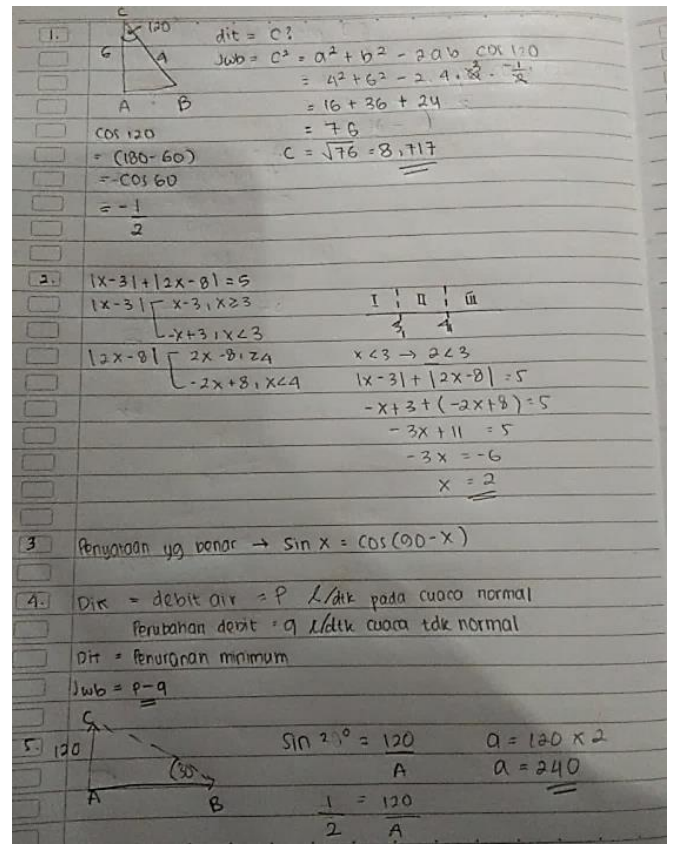

Fig. 11. Results of $\mathrm{X}$ -

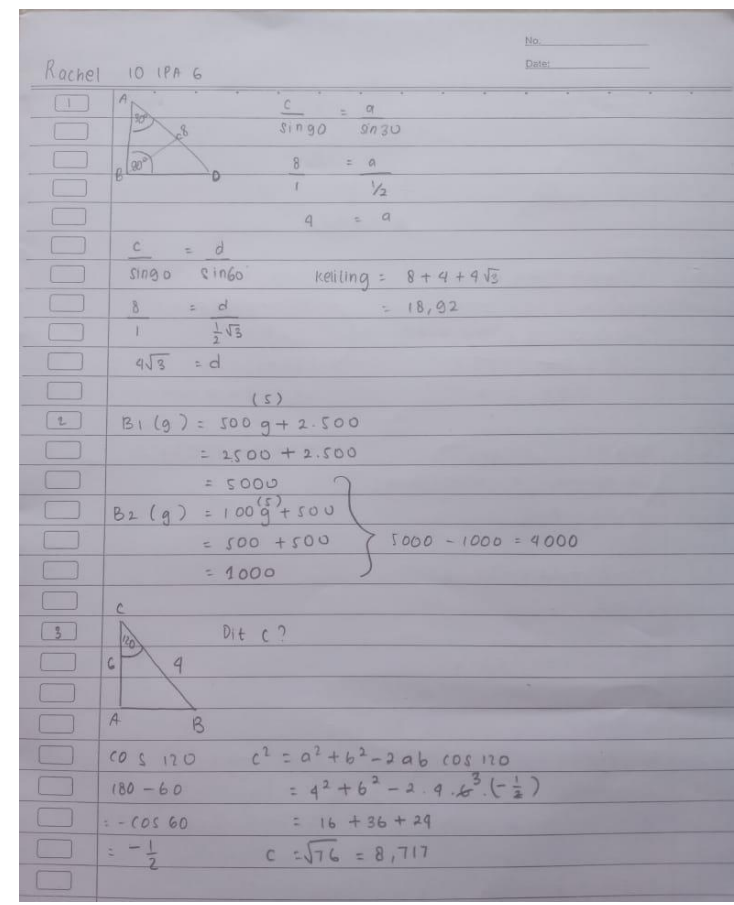

Fig. 12. Results of X-IPA-6 Student Work 
Overall, student learning outcomes in the Large Group Beta Test get good results, namely an average of 70,8 (included in the Effective category) or in other words 55 of 89 students $(61,8 \%)$ exceed the KKM score of 73.Even though there was no direct observation due to the Covid-19 Pandemic conditions, students were still diligent in studying at home and solving the reasoning questions given in the educational game "MENALAR". By playing the "MENALAR", students are expected to be happy in learning or on the other word "learning while playing" using their smartphones. Then, they gave positive responses from an online questionnaire given via the link http://bit.ly/AngketSiswaMENALAR, and they were very interested too.

Here are some screenshots of student comments on Google Forms in their entirety.

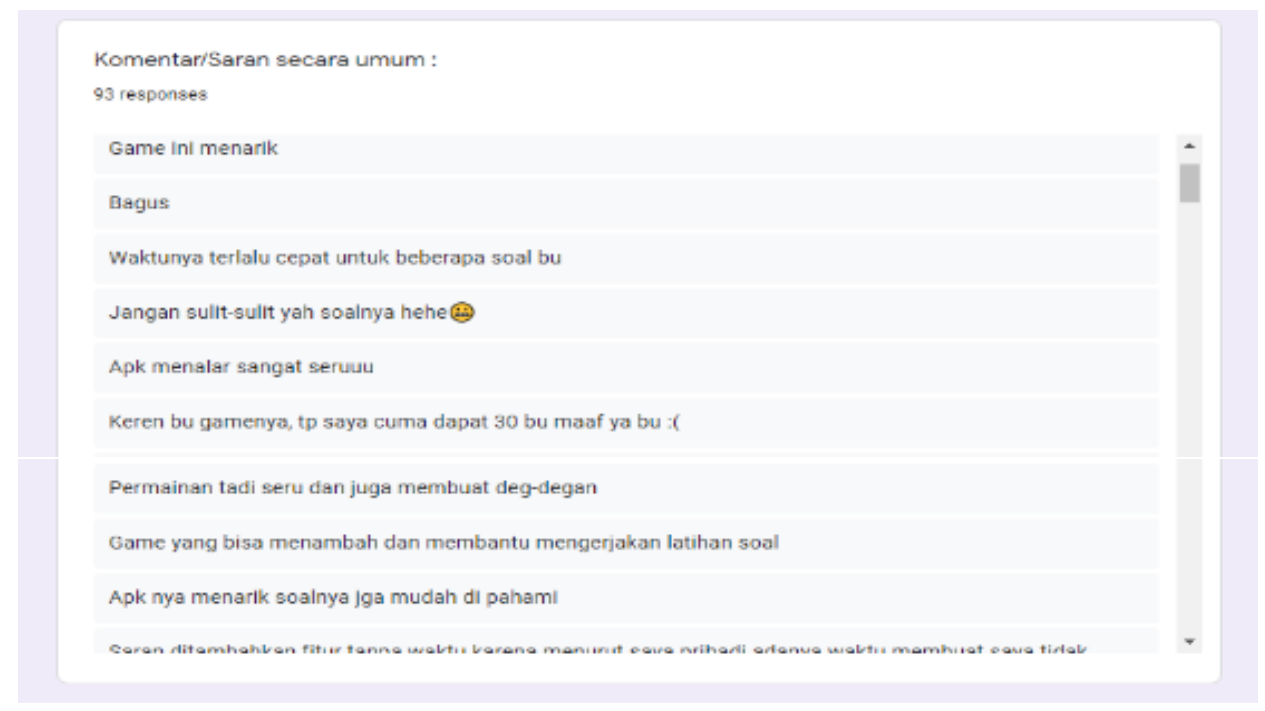

Fig. 13. Student comments on a Google Forms

The use of android educational games can also generate interests and new desires, enhanched stimulation and motivation of learning activities [22], improve student learning outcomes [12], help improve cognitive understanding, as well as presenting material in an attractive and reliable manner [6]. Besides, the position of learning media with game is also a source of independent learning. An educational game not only be used as a learning aid, but can also be used by students with or without the teacher [11].

Several studies about educational games in learning also show the positive impact, especially in mathematics. With educational games developed, it is hoped that it can improve students' thinking skills, as in line with the research results of Aini, Ayu, \& Siswati [5]. Android educational games can also improve students' learning outcomes and affective [14] as well as metacogtive abilities and student learning independence [9]. In addition, one of the goals of developing the educational game "MENALAR" from researchers is to encourage students to actively participate in solving the problems given and think critically about the problems contained in the game. This is in line with the results of research by Rasyid, Gaffar, \& Utari [23].

Overall, according to the validators, the educational game "MENALAR" that was developed had several advantages. The use of the "MENALAR" can be an alternative for distance learning, 
independent learning, increasing student motivation to learn while playing, even though it turns out that the learning results obtained have not shown a score above 80. Furthermore, we know that the nature of the smartphone's application that can be used anytime and anywhere [14], learning media like this can be played at any time so that the use of the media is said to be very practical. In addition, this media is also packaged clearly, the function of buttons is well, the coloring is attractive, and is accompanied by an encouraging backsound in order to build student motivation, so that students are interested in participating in mathematics learning, especially regarding reasoning problems. However, so far, the android educational game "MENALAR" also has limitations, including it cannot be played online, only 15 reasoning questions are given, can only be run on android smartphones, and it has not reached the distribution stage to the Google Play Store due to a longer review.

\section{Conclusion}

Based on the results of the research and development carried out, it can be concluded that the "MENALAR" Educational Game based on Adobe Animation CC which has been developed is in the very valid category with a percentage of $87,6 \%$, very practical with a percentage of $83,6 \%$; and effective with a percentage of $61,8 \%$. Overall, the "MENALAR" are feasible and can be used as an alternative learning media in mathematics learning activities, regarding reasoning problems. The suggestions for the future are to develop similar educational games that are more interesting and their effectiveness can be measured using statistical t-test steps.

Acknowledgements. This research and development can be carried out well due to funding from the Directorate General of Research and Development (Ditjen Risbang) Dikti. Not to forget our gratitude to the Institute for Research and Community Service, University of Balikpapan.

\section{References}

[1] NCTM 2000 Principles And Standards For School Mathematics. Reston, VA: NCTM.

[2] Mikrayanti 2016 Suska Journal of Mathematics Education 297.

[3] Somatanaya, Gde A 2017 Jurnal Teori dan Riset Matematika 155.

[4] Setiawan, T. H 2018 Jurnal Saintika Unpam 156.

[5] Aini, B. O., Ayu, K. C., \& Siswati 2019 Jurnal Teori dan Aplikasi Matematika (JTAM) 374.

[6] Herwinarso, Untung, B., Wirjawan, J. V., \& Pratidhina, E 2020 TEM Journal 9292.

[7] R A Pratama et al 2020 J. Phys.: Conf. Ser. 1613012052.

[8] A Bahauddin and W Setyaningrum 2019 J. Phys.: Conf. Ser. 1320012080.

[9] W Setyaningrum and N H Waryanto 2018 J. Phys.: Conf. Ser. 983012093.

[10] Ismanto, E., Novalia, M., \& Herlandy, P. B 2017 Jurnal untuk Mu negeri 142.

[11] Sari, W., Saputro, S., \& Hastuti, B 2014 Jurnal Pendidikan Kimia (JPK) 397.

[12] Setiyani et al 2019 J. Phys.: Conf. Ser. 1188012067.

[13] Pratama, R. A., \& Waskitoningtyas, R. S 2020 AKSIOMA: Jurnal Program Studi Pendidikan Matematika 9617.

[14] L D Pratama and W Setyaningrum 2018 J. Phys.: Conf. Ser. 1097012123.

[15] Suprianto, A., Ahmadi, F., \& Suminar, T 2019 Journal of Primary Education 884. 
[16] Wibawanto, W 2017 Membuat Bermacam Game Android dengan Adobe Animate. Yogyakarta: Penerbit ANDI.

[17] Sugiyono 2017 Metode Penelitian Pendidikan . Bandung: Alfabeta.

[18] Sutopo, H 2009 Pengembangan Model Pembelajaran Pembuatan Aplikasi Multimedia Khususnya Puzzle Game pada Mata Kuliah Multimedia. Jakarta: Universitas Negeri Jakarta.

[19] Rozak, A., Darmadi, \& Murtafi'ah, W 2018 Jurnal Pendidikan dan Ilmu Pengetahuan 1831.

[20] Dasmo, Astuti, I. A., \& Nurullaeli 2017 JRKPF UAD 471.

[21] Yuliana, R. 2017Jurnal Pendidikan Matematika 660.

[22] Hung, C.M., Huang, I., \& Hwang, G.J 2014 J. Comput. Educ 1151.

[23] Rasyid, A., Gafar, A.A., \& Utari, W 2020 Jurnal Mangifera Edu 4107. 